\title{
Economic and Environmental Implications of Turkish Accession to the European Union: A CGE analysis
}

\author{
by
}

\author{
Levent Aydın ${ }^{* 1}$ Mustafa Acar ${ }^{2}$
}

The purpose of this paper is to analyze the economic and environmental implications of possible Turkish accession to the European Union (EU). The paper focuses on the impacts of three main components of Turkey's possible EU membership: i) free movement of labor between EU and Turkey, ii) free movement of capital, iii) burden sharing of Turkey in terms of EU's environmental objectives in the horizon of 2020, i.e. 10 percent reduction of carbon emissions. Among these, particular focus is placed on the influence of the $\mathrm{CO}_{2}$ emission reduction targets in both regions and its consequences on the carbon price in 2020. We estimate the resource allocation effects of EU climate change policies on both regions by taking into account the likely labor movement from Turkey to the EU and capital movement from EU to Turkey in reverse direction. The results show that the different emission targets for both regions bring about a change in comparative advantages and thus a change in interregional competitiveness, which in turn will result in welfare changes. In case of factor mobility, welfare effects of Turkish accession will be higher for Turkey but it will be lower for EU.

Keywords: EU enlargement, climate change, factor mobility, computable general equilibrium modeling, GTAP.

\footnotetext{
* Corresponding author, Tel.: +90 312219 8120; fax: +90 312219 8105. laydin@pigm.gov.tr

${ }^{a}$ Dr., Vice president, General Directorate of Petroleum Affairs, Ministry of Energy and Natural Resources.

${ }^{2}$ Professor of Economics, Kirikkale University, Turkey. acar70@gmail.com
} 


\section{Introduction}

The largest expansion of the EU was accomplished in 2004 when the EU accepted 10 new member states. In J anuary 2007, Romania and Bulgaria also joined, bringing the Union to its current 27 member states. Since then, the EU has continued supporting the enlargement process. But total population of these 12 new members is over 100 million, which corresponds to nearly 30 percent of the current EU population. The control of migration flows that could arise is a major challenge in the context of the integration process and free movement of persons may have to be introduced gradually. Currently, there are three candidate countries -Croatia, Turkey, and Macedonia- and their population sums up to over 100 million.

The possible enlargement of the European Union to welcome Turkey is not only a political issue: it also has important economic implications for both EU and Turkey. First, large real wage disparities between the two regions provide incentives for Turkish labor to migrate to the EU. Second, capital will be mobile across regions and therefore will equate rates of return with the convergence of growth rates in the steady state. On the other hand, market access implies a reduction in technical and non-technical barriers to trade. The Single Market ${ }^{3}$ reduces these by means of mutual recognition and harmonization of technical regulations. Although the customs union between Turkey and the EU -effective since 1996- has already eliminated some of these barriers, it appears that substantial further advances can be made. Third, even though the international community was not able to reach a binding climate agreement at Copenhagen summit in December 2009, the EU has already declared to adopt policies to mitigate the threat of climate change - as documented by the Fourth Assessment Report of the Intergovernmental Panel on Climate Change (IPCC) - by progressively reducing their $\mathrm{CO}_{2}$ emissions. In its '20-2020' Climate-Energy legislative package, the EU has committed to transforming its energy system to achieve a 20\% reduction in greenhouse gas emissions by 2020 .

As an EU candidate who opened the "Environment" chapter for negotiations, Turkey is now in a position to adopt a policy compatible with EU's climate change policy. Accordingly, it is time to evaluate the impact of adopting such a climate change policy on Turkish economy.

There will be 3 main scenarios to assess the implications of each factor mentioned above: free movement of labor, free movement of capital, and carbon abatement policies. All of the policy simulations are designed in accordance with the possible enlargement of the European Union with Turkey. In the first simulation, labor is allowed to move freely between Turkey and the EU. Given the existing wage

\footnotetext{
${ }^{3}$ We assume that the EU Single Market Program (SMP) fostered competition, and that economic integration reduced firm market power (Botasso and Sembenelli, 1998).
} 
differential, we expect that certain amount of labor would move from Turkey into EU. The possible enlargement of EU also implies capital mobility as well. The last simulation looks into the likely effect of burden sharing in the context of Turkey's agreement to reduce aggregate carbon emission by 20 percent with respect to 1990 level of emission by the year 2020. The rest of the paper is organized as follows.

The following section discusses the model structure and the data followed by policy scenarios in section 3. The forth section interprets the results. Finally the fifth section comprises a general evaluation and the conclusion.

\section{Model structure and the data}

Before proceeding with the model simulations, we must first adjust the standard GTAP-E model and the database, originally developed by Burniaux and Truong (2002). In this context we introduced some modifications to the GTAP-E model to make it consistent with factor mobility. Below we first show that the structure of the GTAP-E model allows for analysis of the free movement of goods and the carbon mitigation policies. We then modify the standard model by incorporating labor mobility module, using migration database (Gmig2data).

\subsection{Model Structure}

The standard GTAP ${ }^{4}$ or GTAP-E model allows for the bilateral trade of goods and services demanded by both domestic as well as foreign users in accordance with the Armington (1969) assumptions. In the standard GTAP-E model, production factors (land, natural resources, capital, and labor) are assumed to be fixed. So, it is not possible to analyze the effect of factor movements between regions, which is implied by the EU integration. This means that a border opening for a production factor, e.g. labor or capital, cannot be considered simultaneously with the carbon emission policies. Hence, certain modifications in the model are needed.

In order to examine labor mobility, or migration between the EU and Turkey, the standard GTAP-E model was modified using the Global Migration Model ${ }^{5}$ (GMig2) developed by Walmsley and Winter (2005), so that the adjusted model allows for bilateral movement of labor. Unlike in the standard GTAP-E model, the labor factor is now able to cross borders and take part in the production processes of foreign firms in different regions, similar to production commodities. Migration of labor generates an endogenous labor inflow and outflow according to each region's

\footnotetext{
${ }^{4}$ The framework of Standard GTAP model is well documented in chapter 2 of Hertel (1997) and available on the internet (http:// www.gtap.agecon.purdue.edu).

${ }^{5}$ For more details, see Walmsley, Winters and Ahmed (2007), Walmsley, et all, (2006) and Walmsley, et all (2005)
} 
labor demand and supply, and interregional wage differentials (Mansoor and Quilin, 2006). Structure of production is depicted in Figure 1 below.

Figure 1- Production structure of model

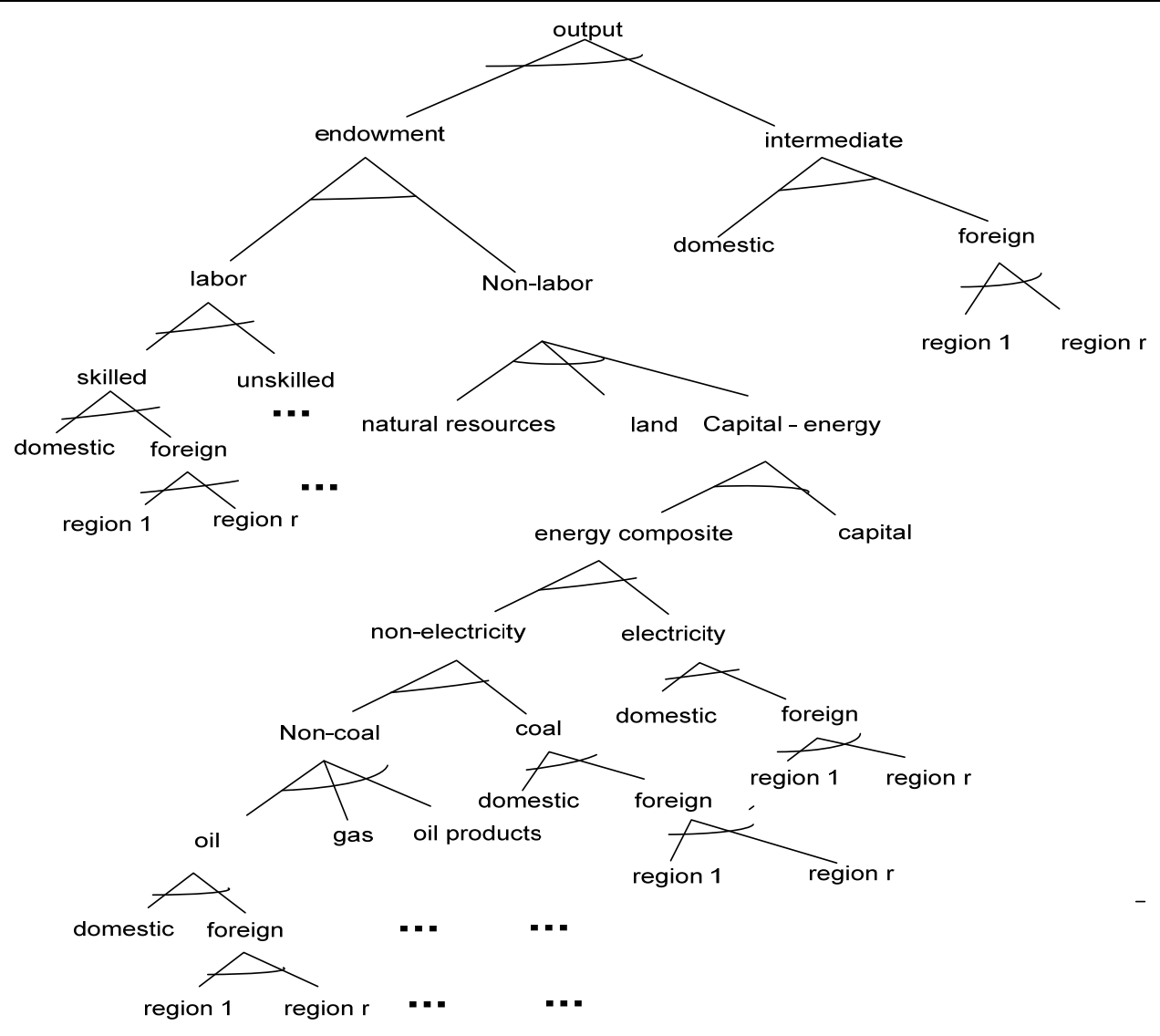

Some important features of the GMig2 model were incorporated for the implementation of the modified GTAP-E model as shown in Figure 1. Labor forces, made up of domestic and foreign labor, are treated as perfect substitutes. Labor supply is allocated across sectors to equate the changes real wages. Migrant income depends on wages but it is decreased by remittances, and migrants do not have income from ownership of capital or land, but do pay taxes. Remittances are constant share of income being added to income of the home region. Real income changes of migrants take into account differences in purchasing power indices (PPP) between home and host regions. Non-movers' income depends on income from factors, taxes and remittances received (Walmsley, Winters, Ahmed, 2007)

In addition, this paper introduces a comparative static long-run extension to the GTAP model which allows capital stock to be treated endogenously. This extension consists of some additions to and modifications of GTAP's structural form and the development of a new closure. It is assumed that capital is mobile across regions and therefore rates of return will get closer with the convergence of growth rates in the steady state. 


\subsection{Data}

The GTAP version 6 database based on the 2001 (Dimaranan and McDougall, 2005) divides the world into 57 regions. For the purpose of this study, i.e. to examine the effects of economic and environmental policies in the context of the enlargement processes, these regions are aggregated to three: EU, Turkey and the rest of the world.

87 industries included in the GTAP version 6 database are aggregated to 7 sectors, predominantly constituted by energy sectors. Since each sector produces only one single commodity, there are 7 commodities produced in the model. Five of them are energy commodities, which release carbon into the atmosphere when they are burned, except electricity.

In the modified production structure, factors of production are divided into two groups: non-labor endowments (including land, natural resources, and capital) and labor endowments (including skilled and unskilled labor). Also, it is assumed that both land and natural resources are sluggish factors, while capital and labor are mobile across sectors as well as regions (see Figure 1 ).

The adjusted database used with the Bilateral Labor Migration Model (GMig2) is based on the GTAP 6.2 Database (Dimaranan, 2005), and it extends to the bilateral migration, skill, and remittance data.

\section{Policy Scenarios}

In order to analyze the economic and environmental impacts of Turkey's accession to the EU, we design three policy scenarios as described below.

Scenario 1- labor mobility between EU and Turkey: In this scenario labor movement across regions is allowed and movements in migrant workers are endogenous. We shock elasticity of labor migration with respect to the wage differential. " Labor force moves from the "home" region to the "host" region depending on the change in real wages. Therefore change in migrants from home region to the host region increases with new migrants and falls with returning migrants. In other words, an increase in the number of migrant workers from labor exporting countries to the labor importing countries reduces the number of workers in the labor exporting country and increases in the importing country.

\footnotetext{
${ }^{6}$ It is assumed that the ratio of wages of migrant relative the wages of permanent residents (p_Beta) is $50 \%$. A Turkish working in the EU has the productivity of the temporary migrant plus half of the difference between the productivity of the temporary migrant and a EU worker. This allows for the fact that the temporary worker is using the host country's technology, which may increase his/her usual productivity
} 
Scenario 2- capital mobility (combined with labor mobility) between EU and Turkey: It is assumed that capital is mobile across regions and therefore rates of return will get equal with the convergence of growth rates in the steady state. In this scenario, following Walmsley (1998), we calculated first the changes -implied by the database- in rates of return necessary to generate the steady state (longrun) database. Then we shocked "rore" (expected rates of returns) for each region to equate the expected rates of return in all regions to an average expected rate of return.

Table 1 gives the shocks to the expected rate of return (rore) required to determine the steady state databases by equalization of expected rate of return in level (ROREXP) across all regions to an average expected rate of return (AVROREXP) in level of $8.77 \%$

Table 1- Change in expected rates of return

\begin{tabular}{lcc}
\hline & $\begin{array}{c}\text { Rore } \\
(\%)\end{array}$ & $\begin{array}{c}\text { Change in } \\
\text { rore }(\%)\end{array}$ \\
\hline EU & 8.35 & 5.05 \\
Turkey & 9.42 & -6.86 \\
Rest of World & 8.94 & -1.85
\end{tabular}

Source: Own calculations by using Appendix 3 of Walmsley (1998)

Table 1 also indicates that in order to achieve a common steady state expected rate of return across all regions, expected rate of return of Turkish economy need to fall by $6.86 \%$ while the expected rate of return of EU economies must rise by $5.05 \%$ This results from the relative expected rate of returns in the standard benchmark database; the expected rate of return in Turkish economy are higher $(9.42 \%)$ than the average expected rate of return, while the expected rate of return for EU economies are lower (8.35\%) than the average expected rate of return.

Scenario 3- reduction of carbon emission under labor and capital mobility between EU and Turkey: In order to analyze the economic impact of new energy and climate change policy of the EU (commonly known as '20/20/20' policy) on Turkish economy in case of accession, it is necessary first to design the policy scenarios relevant for Turkish energy policy in line with EU targets. According to this policy scenario the target emission reduction of $\mathrm{EU}^{7}$ is $20 \%$ with respect to its 1990 level, while emission reduction target for Turkey ${ }^{8}$ is $10 \%$ with respect to its 2010 level.

\footnotetext{
${ }^{7} 20 \%$ nominal rate is the rate of reduction with respect to 1990 level; target rate is the rate of reduction with respect to 2012-2020 average determined by the estimated growth in emissions (implied by GDP growth projections) and nominal rate of reduction (OECD, 1999). Target rate was calculated by the ratio of $\mathrm{E} 1 * / \mathrm{E} 1 \mathrm{BaU}-1$. Where $\mathrm{E} 1 \mathrm{BaU}=(1+\mathrm{g})^{\wedge}(30) \mathrm{E} 0$ and $\mathrm{E} 1^{*}=(1-\mathrm{x}) \mathrm{E} 0, \mathrm{x}(=20 \%)$ represent the target reduction in the year of 2020 , with respect to the level of emissions in 1990 and $g(=0,84)$ is average
} 


\section{Simulation Results}

The model was solved for these scenarios using GEMPACK ${ }^{9}$ software. In this section, first the macroeconomic impact of the movement of labor on regional GDP, terms of trade, imports, exports and factor returns etc. will be presented. Second, the sectoral implications of the movement of labor in both the labor-importing and labor-exporting regions will be presented.

\subsection{Impacts of labor mobility}

The results of simulation 1 are presented in Table 2 . It is estimated that, as a result of changes in real wages, the number of unskilled labor force increases in the EU by 192.2 thousands and skilled labor by 17.9 thousands while decreasing in Turkey by the same amount.

These changes in labor supply will obviously affect real GDP through production changes. As such, increase in the supply of labor in EU leads to a rise in real GDP by 0.19 percent, while the falling labor supply in Turkey reduces real GDP by 0.26 percent. Normally, we expect real wages of unskilled and skilled labor would fall in the EU due to the increase in labor supply. But, it is interesting to note that the real wages of skilled labor increases $(0.07 \%)$ in the EU despite increasing supply of skilled labor $(0.09 \%)$ due to the impact of remittances and changes in terms of trade.

The decreasing labor supply in Turkey also causes output to fall, resulting in improvement of terms of trade and appreciation of exchange rate. This appreciation causes exports to decrease by $0.76 \%$ Imports increases by $0.06 \%$ due to the rising real income $(0.21 \%)$ in home region.

Trade balance in the EU tends to deteriorate as prices fall, but import prices falls more than export prices and the resulting increase in demand for EU imports

growth in emissions in the baseline scenario. By this formula, $20 \%$ nominal rate of reduction corresponds to $37.5 \%$ target rate.

${ }^{8} 10 \%$ nominal rate is the rate of reduction with respect to 2010 level; target rate is the rate of reduction with respect to 2010-2020 average determined by the estimated growth in emissions (implied by GDP growth projections) and nominal rate of reduction (OECD, 1999). Target rate was calculated by the ratio of $\mathrm{E} 1{ }^{\star} / \mathrm{E} 1 \mathrm{BaU}-1$. Where $\mathrm{E} 1 \mathrm{BaU}=(1+\mathrm{g})^{\wedge}(10) \mathrm{E} 0$ and $\mathrm{E} 1^{*}=(1-\mathrm{x}) \mathrm{E} 0, \mathrm{x}(=10 \%)$ represent the target reduction in the year of 2020 with respect to the level of emissions in 1990 and $g(=1.0)$ is average growth in emissions in the baseline scenario. By this formula, 10\% nominal rate of reduction corresponds to $18.7 \%$ target rate.

${ }^{9}$ GEMPACK is developed at the Centre of Policy Studies in the Faculty of Business and Economics at Monash University 
outweighs the increase in EU demand for exports. The current account on the other hand, which takes into account remittance flows, tends to decline as more remittances leave the EU countries. Returns to capital increase as greater labor supply and demand for goods increases the demand for capital. The increased return to capital causes investment to increase, and in the long term this would result in even higher capital stocks and production, which will be discussed in the second scenario.

The opposite is true in the labor-exporting Turkish economy. As the supply of labor falls, real wages rise, production and real GDP fall. The rise in real wages also results in an increase in the real exchange rate and deterioration in the trade balance. But this is offset by the remittances coming from EU which cause the current account balance to improve.

Table 2- Economic impact of Labor mobility

\begin{tabular}{lrr}
\hline Macroeconomic Variable & Turkey & \multicolumn{1}{c}{ EU } \\
\hline Change in the number of unskilled labor(thousand) & -192.25 & 192.25 \\
Change in the number of skilled labor(thousand) & -17.95 & 17.95 \\
Change in the labor supply of unskilled (\%) & -0.61 & 0.52 \\
Change in the labor supply of skilled (\%) & -0.43 & 0.09 \\
Real GDP (\%) & -0.26 & 0.19 \\
Terms of Trade (\%) & 0.15 & -0.01 \\
Change in trade balance (\$ m) & -314 & $-2,458$ \\
Change in current account balance (\$ m) & 123 & $-2,860$ \\
Exports (\%) & -0.76 & 0.11 \\
Imports (\%) & 0.06 & 0.20 \\
Investment (\%) & -0.44 & 0.26 \\
Real Wage Unskilled (\%) & 0.36 & -0.26 \\
Real Wage Skilled (\%) & 0.17 & 0.07 \\
Real Return to Capital (\%) & -0.17 & 0.15 \\
Welfare (household utility, \%) & 0.41 & 0.17
\end{tabular}

Source: Simulation results.

Table 3 shows the output gains to the labor importing EU economies across all sectors (except oil and gas) from the unskilled and skilled migrants. The gains in output are greatest $(0.19 \%)$ in the energy intensive and other industries and services. The relative size of the sectoral output gains from increased unskilled and skilled workers depends on the relative use of skilled and unskilled labor by the sector. Hence there is a tendency for agriculture and other industries and services 
sectors to gain more from unskilled migrants than skilled and for coal, oil and gas to gain more from skilled labor per new migrant worker in the labor-importing EU economies.

Table 3- Impact of labor mobility on sectoral output

\begin{tabular}{lcc}
\hline & Turkey & EU \\
\hline Agriculture & -0.14 & 0.14 \\
Coal & -0.20 & 0.13 \\
Oil & -0.10 & -0.05 \\
Gas & -0.98 & -0.08 \\
Oil Products & -0.02 & 0.09 \\
Electricity & -0.10 & 0.08 \\
Energy Intensive Industries & -0.65 & 0.19 \\
Other Industries and services & -0.27 & 0.19 \\
\hline
\end{tabular}

Source: Simulation results.

Table 3 also shows the output losses to the labor labor-exporting Turkish economy across all sectors from the unskilled and skilled labor leaving the country. The losses are greatest in energy intensive sectors $(0.65 \%)$, and the loss of unskilled labor has a greater impact on this sector which use unskilled labor most intensively and likewise for skilled.

\subsection{Impacts of labor mobility combined with capital mobility}

The second simulation investigates the combined effects of capital and labor mobility. Long run closure is used in this simulation so that the model is able to capture long run effects of capital mobility. In this case, sufficient time passes for changes in investment to result in changes in the regional capital available for production. Endogenously determined capital stocks adjust to changes in demand for capital. This accumulation effect is determined by setting the current regional rates of return in the period simulated equal to the expected regional rates of return. The long run macroeconomic effects of capital and labor mobility in the context of EU enlargement are reported in Table 4.

In the long run the availability of capital within a region is no longer fixed. Any increase in demand for domestic production will increase the demand for and hence the supply of capital in Turkish economy. Supply response is restricted only by the condition that global investments can be financed by global savings. As a result production in Turkey is no longer constrained by the fixed supply of capital; accordingly real GDP increases further in Turkish economy. 
Table 4- Economic impact of capital and labor mobility

\begin{tabular}{lcc}
\hline Macroeconomic Variable & Turkey & EU \\
\hline Change in the number of unskilled labor(thousand) & -163.62 & 163.62 \\
Change in the number of skilled labor(thousand) & -15.36 & 15.36 \\
Change in the labor supply of unskilled (\%) & -0.51 & 0.50 \\
Change in the labor supply of skilled (\%) & -0.37 & 0.09 \\
Real GDP (\%) & 4.16 & -3.18 \\
Terms of Trade (\%) & -0.73 & 0.09 \\
Change in trade balance (\$ m) & -737 & 35,137 \\
Change in current account balance (\$ m) & -368 & 35,585 \\
Exports (\%) & 2.89 & -2.37 \\
Imports (\%) & 3.93 & -3.56 \\
Investment (\%) & 9.12 & -7.36 \\
Real Wage Unskilled (\%) & 3.50 & -2.74 \\
Real Wage Skilled (\%) & 3.08 & -2.41 \\
Real Return to Capital (\%) & -4.69 & 3.64 \\
Capital Stock (\%) & 9.20 & -7.30 \\
Rental price of capital (\%) & -5.17 & 3.72 \\
Welfare (household utility, \%) & 3.84 & -2.63 \\
\cline { 2 - 3 } Source: Simulation results. & &
\end{tabular}

The adjustment mechanism of factor endowment in the two regions is as follows: Substitution between labor and capital occurs with respect to the wedge between wage rate and capital rental rate. The higher relative real wages (unskilled (3.5\%) and skilled (3.08\%) and lower relative rentals $(-5.17 \%)$ in Turkey will cause an increase in demand for and thus endogenously determined capital stock (9.2\%). On the other hand in the EU economies higher relative rental prices cause substitution away from the capital, therefore capital stocks fall. Furthermore changes in capital stocks are positively related to changes in the real GDP. Therefore real GDP increases by $4.16 \%$ in Turkey whereas it decreases by $3.18 \%$ in EU.

The model is consistent with standard trade theory - countries benefiting from inward migration experience a decline in the marginal product/ wage of labor as they move down their marginal product curves, and production increases as firms gain greater access to cheaper labor. Returns to capital increase as capital becomes scarce relative to labor. The reverse is true for those countries experiencing outward migration (Walmsley, 2008). 
The EU economies experience decreases in real GDP as a result of the overweight of decreased supply of capital while increased supply of labor which can be used in production ${ }^{10}$. The greater impact of decreasing capital on production causes decrease in output and result in improve in terms of trade $(0.09 \%)$ and exchange rate. The appreciation of exchange rate decreases in export (2.37\%) and import also decreases by $3.56 \%$ due to the falling income. However the increased in capital causes to increase in output and result in losses in the terms of trade $(0.73 \%)$ and the deprecation of exchange rate and this deprecation of national currency give rise to the increase in export by $2.89 \% \mathrm{~A}$ rise in income in Turkey increases foreign demand thus import increases by $3.93 \%$ The most important macroeconomic variable indicating which economies will gain or lost is the regional welfare or utility of the regional household. The regional welfare rises in Turkey by $3.84 \%$ while it decreases in the EU by $2.63 \%$

Table 5- Impact of labor and capital mobility on sectoral output

\begin{tabular}{lcc}
\hline Sectors & Turkey & EU \\
\hline Agriculture & 1.63 & -1.24 \\
Coal & 7.06 & -4.12 \\
Oil & 2.27 & -2.27 \\
Gas & 20.87 & -4.30 \\
Oil Products & 5.28 & -4.15 \\
Electricity & 6.70 & -5.22 \\
Energy Intensive Industries & 2.90 & -2.87 \\
Other Industries and services & 4.65 & -3.27 \\
\hline Source: Simulation results & &
\end{tabular}

Table 5 indicates that rise in output are largest to the capital intensive energy sector of Turkish economy such as gas $(20.87 \%)$, coal $(7.06 \%)$, electricity $(6.7 \%)$ and oil products(5.28\%). Whereas the fall in output are the largest to the same sectors, respectively gas $(4.3 \%$, coal $(4.12 \%)$, oil products $(4.15 \%)$ and electricity $(5.22)$ for EU countries as shown same table.

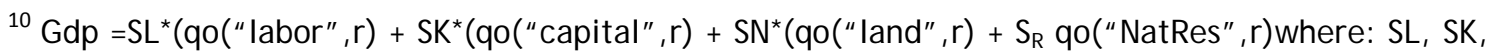
SN and SR are the shares of labor, capital, land and Natural Resources in GDP. qo("NatRes",r) and qo( "Iand", r) are exogenously equal to zero in all closures.
} 


\subsection{Impact of reduction of carbon emission under capital and labor mobility}

In this scenario the labor and capital are mobile and carbon emission constraint deriving from the new energy and climate change policies commonly known as $20 / 20 / 20$ strategies are implemented. In this section scenario 3 is compared to the scenario 2 to see the net effects of emission reduction for EU (20\% reduction target with respect to the 1990 level) and for Turkey (10\% reduction target with respect to the 2010 (evel).

Comparing the results of scenario 3 with scenario 2, these emission targets in both regions lead to decrease in real GDP from $4.16 \%$ to $0.85 \%$ in Turkey and from $-3.18 \%$ to $-5.95 \%$ in EU. Table 6 also shows the emission reduction of Turkey and EU relative to the reference year levels and corresponding marginal abatement costs in the absence of the emission trading or other flexibility mechanism. The EU will have to reduce carbon emission by $37.5 \%$ (See footnote 7 ) to meet the target in the commitment period of 2012-2020, and the corresponding marginal abatement cost (MAC) is 52.56 USD per ton of carbon. The Marginal abatement cost for Turkey is determined as 18.7 USD per ton of carbon (See footnote 8). As would be expected, the marginal abatement cost for Turkey is lower than EU due to the lower target and less carbon intensive country.

Table 6- Economic impact of carbon emission reduction

\begin{tabular}{lcc}
\hline & Turkey & EU \\
\hline Real GDP \% & 0.85 & -5.95 \\
Terms of Trade \% & -0.19 & 0.29 \\
Marginal Abatement Cost (\$ per ton C) & 18.87 & 52.56 \\
Emission Reduction \% & -18.5 & -37.5 \\
Exports \% & -5.11 & -1.67 \\
Imports \% & -0.76 & -6.73 \\
Investment \% & 3.57 & -11.62 \\
Real Wage Unskilled \% & -0.02 & -5.92 \\
Real Wage Skilled \% & -0.06 & -5.46 \\
Real Return to Capital \% & -5.69 & 1.98 \\
Capital Stocks \% & 3.57 & -11.62 \\
Welfare (utility of regional Household \%) & 1.01 & -5.12 \\
\hline
\end{tabular}

Source: Simulation results.

In general, carbon tax causes all price indices to rise in both regions. But terms of trade falls $(0.19 \%)$ in Turkey because of the import prices increase $(0.4 \%)$ more 
than export prices $(0.22 \%$. The reverse is true for the EU: terms of trade improve by $0.29 \%$ The effects of capital mobility on capital stocks, investment and welfare are relatively smaller compared to the no carbon constraint case, as shown in Table 6.

Table 7 reports that under carbon constraint, output of agriculture and 'other industries and services' will expand in Turkey while output of energy sectors like gas, coal and electricity will decline dramatically. All sectors contract in the EU.

Table-7: Percentage change in sectoral output of carbon abatement

\begin{tabular}{lcc}
\hline & Turkey & EU \\
\hline Agriculture & 0.43 & -3.15 \\
Coal & -33.75 & -57.08 \\
Oil & -0.52 & -8.86 \\
Gas & -93.1 & -34.44 \\
Oil Products & -0.67 & -17.14 \\
Electricity & -6.34 & -17.24 \\
Energy intensive sectors & -12.29 & -10.63 \\
Other Industries and Services & 0.99 & -5.93 \\
\hline
\end{tabular}

Source: Simulation results.

Finally, Table 8 compares carbon abatement costs with respect to factor mobility. As indicated by the Table 8 and figures of 2 and 3 presented in Appendix indicate that there will be considerable deviation of MAC with factor mobility: for a given carbon price, there will be higher emission reduction rate in the EU in case of mobile factors. The reverse is true for Turkey, as capital moves from EU towards Turkey and investments hence capital stock expand, Turkish economy moves toward more carbon-intensive economy.

Table 8- change in carbon emission reduction rate due to the factor mobility

\begin{tabular}{ccccc}
\hline \multirow{2}{*}{$\begin{array}{c}\text { Carbon Prices } \\
\$ / \text { ton } C\end{array}$} & \multicolumn{2}{c}{ Turkey } & \multicolumn{2}{c}{ EU } \\
\cline { 2 - 5 } & No Mobility & Mobility & No Mobility & Mobility \\
\hline 0 & 0.0 & 0 & 0.0 & 0 \\
5 & -9.22 & -3.9 & -7.35 & -11.6 \\
10 & -15.53 & -10.6 & -12.86 & -16.9 \\
20 & -24.74 & -20.5 & -20.71 & -24.4 \\
30 & -31.46 & -27.7 & -26.28 & -29.7 \\
40 & -36.70 & -33.3 & -30.54 & -33.7 \\
50 & -40.97 & -37.8 & -34.32 & -37.0 \\
\hline
\end{tabular}

Source: Simulation results. 
In case of factor mobility in the context of EU enlargement, the downward shift in the marginal abatement cost curve ${ }^{11}$ for Turkey indicates lower emission reduction with respect to the no mobility case. Conversely, the upward shift in the marginal abatement cost curve for EU indicates higher emission reduction with respect to the no mobility case.

\section{Conclusion}

This paper addresses three main issues related to the EU enlargement between EU and Turkey using a general equilibrium modeling framework in order to measure economic and environmental effects on macroeconomic aggregates and changes in sectoral production: labor mobility (from developing Turkey to developed EU; capital mobility combined with labor mobility; carbon abatement policies.

One of the main arguments for cross-border labor migration in the economics literature is related to wage differentials between the host and sending country. It is argued that the probability of migration is positively related to the size of any wage or income differential. Results of the first scenario indicate that roughly 200 thousand unskilled and 20 thousand skilled labors will migrate from Turkey to EU. Note that this is the result determined only by real wage differentials, omitting some other important factors affecting migration decision such as transaction costs, marital status, and social involvement in the region of residence.

Even though Turkey has been on the rise in recent years with regard to many macroeconomic indicators, the unemployment rate is still high -11\%as of today. In addition, Turkey still has to go through structural changes on the road ahead. Bearing this in mind, the number of labor migrants from Turkey to EU is not terribly high, which is only $0.8 \%$ of labor force.

The second scenario is based on long run closure, which allows considering the restructuring of sectors and the interaction of migration with capital movements. Since the EU is relatively capital abundant $(K / L=1.36)$ and Turkey is relatively labor abundant $(K / L=1.02)$ the production factors (labor and capital) move from two directions opposite to each other. Results of scenario 2 indicate that EU will suffer from factor movements for the enlarged EU: the real GDP decreases by about 3.18 percent. Total net factor income at market prices decreases by 2.32 percent. The labor market effects are also considerable: in the long-run, wages decline by about 2.5 percent, and the real return to capital increases by about 3.72 percent. Conversely, the real GDP in Turkey increases by about 4.16 percent, and the real wages increase by about 3.5 percent, the real return to capital decreases by about 5.17 percent, and the total net factor income increases by 2.65 percent.

\footnotetext{
${ }^{11}$ The concept of a marginal abatement cost curve( MACC) has been adopted largely for climate policy analyses in the context of a general equilibrium framework. It is argued that an economy as a whole can be treated like a production plant, and hence the concept of a MACC can be applied analogously. Intuitively then, a MACC for an economy represents the social cost of a the last unit of emissions abated in the economy
} 
We should also note that the paper does not cover some aspects of labor migration. For instance, returning migrants may give a boost to economic growth by bringing in capital, skills and new ideas acquired abroad, which may offset the initial losses caused by brain drain.

It is expected that the emission reduction target of new EU energy and climate change strategies leads to lower production especially in the energy sectors in both regions, while increasing production in agriculture and other industries and services in Turkish economy. The marginal abatement costs represent production cost or dead-weight loss to the economies imposing carbon constraint. These costs induce substitution of fossil fuels (coal versus natural gas) as well as fuel-nonfuel (capital versus energy), leading to using less energy. Those industries intensively using energy commodities on which carbon taxes are imposed (coal, gas, oil products) will suffer from deterioration competitiveness. On consumption side, the higher energy prices imply a change in consumption pattern. In this context, welfare effects are positive for Turkey while they are negative for EU, and these effects deteriorates with carbon taxes for both regions.

As to the political economy of Turkish accession to the EU, the economic impact joining the EU will be clearly positive. This will follow from the fact that Turkey will benefit from increased economic stability and higher foreign investment flows, as well as continued EU supervised legal and political reforms. If Turkey continues to realize its growth potential over coming decades as it has been doing recently, economic and political outlook of the country will be a very different by the time it joins the EU. It is true that it will still be one of the poorest EU economies with respect to per capita income and probably will have the largest agricultural sector; but Turkey's level of economic development will be comparable to the levels reached by many new, as well as senior EU countries. 


\section{References}

Armington, P.S., 1969. A Theory of Demand for Products Distinguished by Place of Production, IMF Staff Papers 16, 159-178.

Burniaux, J . and T. Truong 2002. GTAP-E: An Energy-Environmental version of the GTAP Model. GTAP Technical Paper No. 16, Center for Global Trade Analysis, Purdue University, West Lafayette, IN.

Dimaranan, B.V., and R.A., McDougall, 2005. Global trade, assistance, and production: The GTAP 6 Data Base, Center for Global Trade Analysis, Purdue University.

Hertel, T. W. (editor) 1997. Global Trade Analysis: Modeling and Applications, Cambridge University Press.

Mansoor, A., Quilin, B., 2006. Migration and remittances: Eastern European and the Former Soviet Union, Worldbank publication.

OECD, 1999. Action against Climate Change: The Kyoto Protocol and Beyond.

Walmsley, T.L., S. A., Ahmed and Christopher R. P. 2006. The GMig2 data base: A Data base of bilateral labor migration, wages and remittances. GTAP Research Memorandum, 6, Center for Global Trade Analysis, Purdue University, IN, USA.

Walmsley, T.L., L. Alan Winters, and S. Amer Ahmed 2007. Measuring the impact of the movement of labor using a model of bilateral migration flows, GTAP Technical Paper No. 28, Center for Global Trade Analysis, Purdue University, West Lafayette, IN, USA.

Walmsley, T.L. and L.A. Winters 2005. Relaxing the restrictions on the temporary movement of natural persons: A Simulation analysis, Journal of Economic Integration, December, 20(4).

Walmsley, T., S.A., Ahmed and C., Parsons, 2005. The Impact of liberalizing labor mobility in the Pacific Region. GTAP Working Paper No. 31 revised 2009.

Walmsley, T., 2008, Long-Run Simulations with GTAP: Illustrative Results from APEC Trade Liberalization, GTAP Technical Paper No. 9 


\section{Appendix}

Figure 2- Shifts in marginal abatement cost curve for Turkey

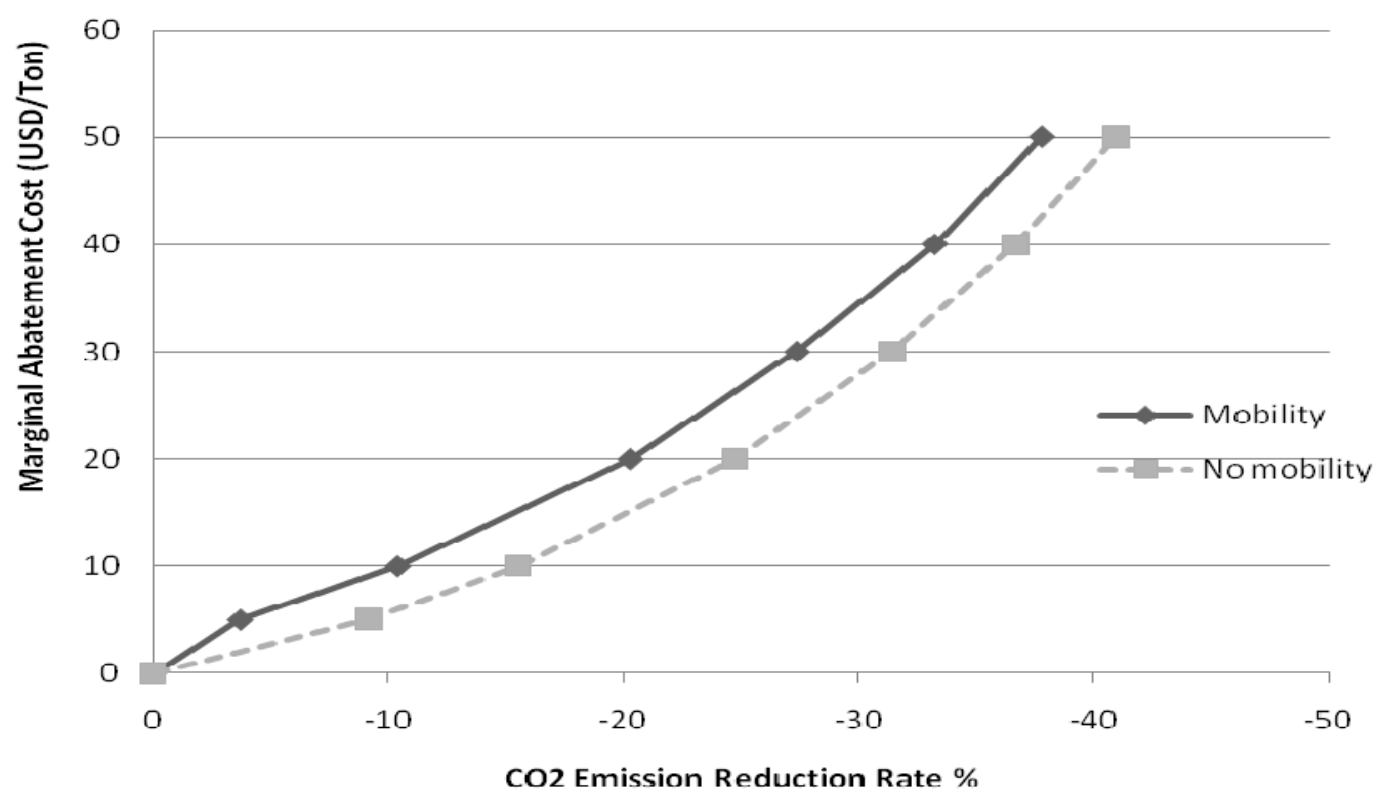

Figure 3- Shifts in the marginal abatement cost curve for EU



